Henriette Christiansen

\title{
Arktisk symbolsk politik - eller hvorledes skal vi forstå den grønlandske idé om selv- stændighed?
}

\author{
"Umuligt nu langer at blive i ro, \\ kalaallit, ' mod store mål vi stavner: \\ Som fribarne folk vi i landet vil bo \\ begynd at tro på jeres evner!" \\ (Uddrag af Gronlands nationalsang \\ af Henrik Lund")
}

I debatten om gronlandsk selvstændighed politiseres kulturelle argumenter og politik etnificeres. Dette tydeliggor. hvordan Gronland - selv efter 20 år med hjemmestyre - prages af et sákaldt kolonialt syndrom. Det skaber en splittelsens diskurs. Begrebet udtrykker den udbredte opfattelse af en stereotypificeret splittelse mellem gronlandskhed $\mathrm{og}$ danskhed. Disse to kategorier opfattes som antitetiske og begrundes i en grundlieggende væsensforskellighed, der skaber etniske, kulturelle, sociale, sproglige og okonomiske skillelinier tvars igennem det gronlandske samfund. Det er problematisk at begrunde det gronlandske onske om selvstandighed $i$ en sådan identitetsopfattelse. For 1990'ernes gronlandske samfund er i udbredt grad karakteriseret ved blandinger og skillelinier på tværs af de etniske grupper. Selvstandighedsønsket dakker derfor i høj grad over et skisma mellem ideologi og praksis - mellem normer om kulturel vesensforskellighed og et liv karakteriseret ved en sociookonomisk og kulturel udvikling praget af interaktivitet og hybriditet.

Efter 20 år med hjemmestyre befinder Grønland sig fortsat $\mathrm{i}$ en nationsdannelsesproces. I denne proces har udviklingen af en stærk og positiv national selvforståelse stor betydning for etableringen af en integreret nation - og måske $\mathrm{i}$ fremtiden for skabelsen af en selvstændig stat. Når selvstændighedskrav fremsættes, er det naturligt at sætte lup på den kulturelle identitet, som udgør baggrunden for et sădant ønske. For kultur og politik bør ikke og kan ikke opfattes som klart adskilte sfærer. I det grønlandske tilfælde resulterer dette $i$ et fokus på arven fra kolonitiden.

Inden blikket vendes mod den gronlandske kontekst, vil jeg indlede med en teoretisering omkring kulturel identitet og muligheden for politisering af samme.

\section{Kulturel identitet}

Der findes mange fortolkninger af, hvad kultur og kulturel identitet er. Jeg vil tage udgangspunkt i den socialkonstruktivistiske diskurs, som i disse år har stor betydning inden for antropologisk forskning. Inden for denne diskurs finder man teoretikere som Benedict Anderson, Thomas Hylland Eriksen og danskeren Bo Wagner Sørensen.

Inden for den socialkonstruktivistiske diskurs forstås kultur som praksis. Kultur skabes dag for dag og er udtryk for løbende erfaringer, konkrete valg og aktuelle behov. Der findes ikke en egentlig objektiv, identificerbar væsensforskellighed, som adskiller en kultur fra en anden. Der findes blot folkelige forestillin- 
Henriette Christiansen

\title{
Arktisk symbolsk politik - eller hvorledes skal vi forstå den grønlandske idé om selv- stændighed?
}

\author{
"Umuligt nu langer at blive i ro, \\ kalaallit, ' mod store mål vi stavner: \\ Som fribarne folk vi i landet vil bo \\ begynd at tro på jeres evner!" \\ (Uddrag af Gronlands nationalsang \\ af Henrik Lund")
}

I debatten om gronlandsk selvstændighed politiseres kulturelle argumenter og politik etnificeres. Dette tydeliggor. hvordan Gronland - selv efter 20 år med hjemmestyre - prages af et sákaldt kolonialt syndrom. Det skaber en splittelsens diskurs. Begrebet udtrykker den udbredte opfattelse af en stereotypificeret splittelse mellem gronlandskhed $\mathrm{og}$ danskhed. Disse to kategorier opfattes som antitetiske og begrundes i en grundlieggende væsensforskellighed, der skaber etniske, kulturelle, sociale, sproglige og okonomiske skillelinier tvars igennem det gronlandske samfund. Det er problematisk at begrunde det gronlandske onske om selvstandighed $i$ en sådan identitetsopfattelse. For 1990'ernes gronlandske samfund er i udbredt grad karakteriseret ved blandinger og skillelinier på tværs af de etniske grupper. Selvstandighedsønsket dakker derfor i høj grad over et skisma mellem ideologi og praksis - mellem normer om kulturel vesensforskellighed og et liv karakteriseret ved en sociookonomisk og kulturel udvikling praget af interaktivitet og hybriditet.

Efter 20 år med hjemmestyre befinder Grønland sig fortsat $\mathrm{i}$ en nationsdannelsesproces. I denne proces har udviklingen af en stærk og positiv national selvforståelse stor betydning for etableringen af en integreret nation - og måske $\mathrm{i}$ fremtiden for skabelsen af en selvstændig stat. Når selvstændighedskrav fremsættes, er det naturligt at sætte lup på den kulturelle identitet, som udgør baggrunden for et sădant ønske. For kultur og politik bør ikke og kan ikke opfattes som klart adskilte sfærer. I det grønlandske tilfælde resulterer dette $i$ et fokus på arven fra kolonitiden.

Inden blikket vendes mod den gronlandske kontekst, vil jeg indlede med en teoretisering omkring kulturel identitet og muligheden for politisering af samme.

\section{Kulturel identitet}

Der findes mange fortolkninger af, hvad kultur og kulturel identitet er. Jeg vil tage udgangspunkt i den socialkonstruktivistiske diskurs, som i disse år har stor betydning inden for antropologisk forskning. Inden for denne diskurs finder man teoretikere som Benedict Anderson, Thomas Hylland Eriksen og danskeren Bo Wagner Sørensen.

Inden for den socialkonstruktivistiske diskurs forstås kultur som praksis. Kultur skabes dag for dag og er udtryk for løbende erfaringer, konkrete valg og aktuelle behov. Der findes ikke en egentlig objektiv, identificerbar væsensforskellighed, som adskiller en kultur fra en anden. Der findes blot folkelige forestillin- 
ger om kulturers grundlaggende vesensforskellighed - den saikaldte essenstankning. Dette skyldes, at mennesket har et behov for at kategorisere os og dem for på denne måde at skabe orden og stabilitet i ens tankeunivers. Dette kaldes ofte stabilitetsprincippet.

Inden for den socialkonstruktivistiske diskurs er man således ikke gronlandsk. men man kan pákalde sig forskellige identiteter alt afhrengig af den givne situation. Socialkonstruktivismen taler i den forbindelse om identitetscirkler forstået på den måde, at man sagtens kan vare både gronlandsk, dansk, mor og okonoma på samme tid. Flere identiteter kan derfor supplere hinanden, og hybrider kan skabes. Identitet er ikke et mærke eller en skæbne, som er ufravigelig, selvom den kan opfattes som sådan (i hvert fald i nogle sammenhange). Liisa Malkki beskriver identitet således:

"... identity is always mobile and processual, partly self-construction, partly categorization by others, partly a condition, a status, a label, a weapon, a shield, a fund of memories, et cetera. It is a creolized aggregate composed through bricolage" (Malkki, 1992)

Identitet skabes og konstrueres altså hver dag i samspillet mellem mennesker og i ikke mindst kontrasten til de Andre - den såkaldte kulturelle Anden. Netop identitetsdannelsen i krydsfeltet mellem os og dem er uhyre interessant i det grønlandske tilfælde, hvilket vi skal vende tilbage til senere.

\section{Politisering af kulturel identitet}

Da identitet ikke kan opfattes som en fast og prædestineret storrelse, skabes der potentiale for politisering af den $\mathrm{kul}-$ turelle identitet. Politisering af kultur hentyder til opfattelsen af kultur som ideologisk varktoj eller som politisk redskab. En bestemt ideologi - for eksempel om vasensforskellighed - udstikker så at sige málene, og kulturen kan herefter udgore en væsentlig legitimerende faktor $\mathrm{i}$ den politiske kamp for at nå disse mål, hvilket blandt andet antropologen Thomas Hylland Eriksen understreger (1993b).

Magt og social position er ganske afgorende for det folte behov for politisering af kulturel identitet. Asymmetri skaber behov hos de(n) underkastede for at forsoge at ændre rollefordelingen. Dermed kan kultur og kulturel identitet blive kærkomne midler til at vende situationen for grupper, hvis livssituation præges af diskrimination og subordination.

Etnicitet kan i høj grad også politiseres, og netop i forbindelse med etnicitet bliver magt- og politiseringsaspektet et yderst væsentligt omdrejningspunkt. Grænsedragning mellem etniske grupper fẳ afgorende betydning i opbygningen af henholdsvis en vi-folelse og en os-folelse. Vi-folelse udtrykker en intraetnisk identitetsdannelse på det kollektive plan og markerer et særligt fællesskab inden for den pågældende gruppe. Denne følelse suppleres af en os-folelse, der er udtryk for en inter-etnisk identitetsdannelse, som markerer lukkethed over for den anden/de andre etniske grupper. Hvorvidt disse vi/os-folelser fremhæves tydeligt, er afhængigt af den givne situation og ikke mindst det (magt)forhold, som eksisterer mellem to eller flere etniske grupper. Cocktailen af etnicitet og magt mærkes dog i særlig grad, nár visse etniske grupper oplever en egentlig etnisk stigmatisering på baggrund af et meget asymmetrisk magtforhold, der er centreret omkring en stærkt markeret etnisk skillelinie i samfundet. I forbindelse med en etnisk stigmatise- 
ring vil man i øvrigt se. at det ikke kun er den ene gruppe, som foretager stigmatisering af den anden; tværtimod vil den stigmatiserede gruppe selv underbygge sin etniske identitet som stigmatiseret gennem en identitetsdannelsesproces, som kan sammenlignes med en slags negativ, selvopfyldende spådom.

\section{Politisering af kulturelle argumenter i Gronland}

I Grønland kan man i høj grad konstatere en politisering af kulturel identitet. Som en af mine interviewpersoner forklarede det: "Altså alt, hvad der smager af kultur, er simpelthen indspundet $i$ politik". Dette har de øvrige interviewpersoner $\mathrm{i}$ høj grad givet den pågældende ret $\mathrm{i}$.

\section{Det koloniale syndrom}

På baggrund af den socialkonstruktivistiske tolkning af kultur må man konkludere, at politiseringen af kulturel identitet $\mathrm{i}$ Grønland $\mathrm{i}$ dag må siges at være et resultat af det, som en anden af mine interviewpersoner har kaldt for det koloniale syndrom. Det koloniale syndrom udtrykker, hvorledes grønlandere har følt sig og fortsat føler sig underordnet den danske koloniherres dominans. Den danske kolonisering af Grønland har - på trods af dens relativt milde form - således sat sig dybe spor i den kollektive grønlandske bevidsthed og selvforstáelse samt i den opfattelse af gronlændere, som mange danskere menes at bære rundt på. Det koloniale syndrom kan dermed forstås som den dybereliggende årsag til, at mange grønlændere fortsat opfatter grønlandsk identitet den såkaldte gronlandskhed - som stigmatiseret $\mathrm{og}$ underordnet den sấkaldte danskhed. Denne identitetsopfattelse reproduceres fortsat af begge de to etniske grupper, og de er dermed begge medvirkende til, at den asymmetriske identitetsopfattelse opretholdes selv i 1990'erne.

Det koloniale syndrom må antages kun at have kunnet overleve i de seneste 40-50 år i kraft af det magtforhold, som er iboende selve koloniseringen og som $i$ en vis grad blev fort videre $i$ den dansk dikterede moderniseringsproces, der fulgte i kølvandet på Grønlands integration i det danske rige som amt i 1953. For moderniseringen forte til en udbredt følelse af fremmedgørelse, apati og splittelse blandt mange gronlændere samt en folelse af, at deres livsform og kultur måtte nedtones $\mathrm{i}$ forhold til det moderne - og i deres øjne - danske liv.

I dag er det dog også muligt qua den nationsdannelsesproces, som har taget fart efter hjemmestyrets indførelse, at iagttage en situation, hvor den grønlandske selvopfattelse har ændret sig til noget mere positivt. Denne optimisme og tro på sig selv er også nok så afgørende for det nuværende krav om selvstændighed. Men optimismen er stadig kun en del af den måde, hvorpå mange gronlændere opfatter sig selv, deres livssituation samt relationen til danskerne. $\mathrm{Og}$ netop denne splittelse i den grønlandske selvopfattelse er et vigtigt aspekt, som jeg har mødt i mange af mine samtaler med interviewpersonerne. På den ene side er man stolt over at være grønlænder, men på den anden side sidder det negative billede af gronlænderen også dybt i mange.

I kraft af det historiske magtforhold bibeholder man således en opfattelse af det gronlandske samfund som karakteriseret ved kumulerede og gensidigt forstarkende skillelinier. Etniciteten betragtes som den vigtigste skillelinie, der skærer ned i gennem samfundet og dermed danner to grupper: den domineren- 
de og den dominerede gruppe - os og dem. danskerne og gronlanderne. Som en af de interviewede forskere udtrykker det: "Magt sattes narmest per automatik på det danske/danskerne". Dette sker $i$ hoj grad ogsa i $1990^{\circ}$ erne, hvor folelsen af splittelse og ulighed internt blandt gronlendere samt mellem henholdsvis gronlandere og danskere fortsat er sticrk.

\section{Splittelsens diskurs}

På baggrund af det koloniale syndrom kan man i dag i Gronland konstatere et fanomen, som prager alle samfundets sferer, og som antropologen Bo Wagner Sorensen (1994) kalder splittelsens diskurs. Koloniseringen resulterede $\mathrm{i}$ en slags etnisk dialektik eller en art negativ spejling mellem de to etniske gruppercn dynamik, som fortsat er i spil i Gronland i 1990'erne. Baggrunden for denne splittelse er en tendens til essenstankning, der bevirker, at både danskere og gronlandere gennem tiden har haft den opfattelse, at grupperne adskilte sig indbyrdes i kraft af deres grundlæggende væsensforskellighed. Flere af mine interviewpersoner har săledes forklaret mig, at deres gronlandske identitet indeholder en vis kerne, som adskiller dem fra folk med andre nationale, etniske og kulturelle identiteter. Ifølge denne tankegang findes der derfor en særlig gronlandskhed, som i høj grad er omdrejningspunktet for splittelsens diskurs.

Gronlandskheden reproduceres dagligt, og den tegner et broget billede af den generaliserede gronlenders kulturelle og etniske identitet. Ingen af de personer, som jeg har talt med i Gronland på formel eller uformel vis, har hverken villet eller kunnet definere pracist, hvori den såkaldte gronlandskhed består. Men den står ikke desto mindre meget levende for dem som fol- kemodel og som en mâlestok, op mod hvilken man kan máles og vejes, såfremt man selv definerer sig og defineres af andre som gronlandsk

I mine interviews har jeg ikke spurgt informanterne om den måde, hvorpa de opfatter dansk identitet eller danskhed. Men det interessante er, at interviewpersonerne ofte af sig selv har skelnet mellem det "typisk gronlandske" og det "typisk danske". Gronlandskheden er med andre ord blevet presenteret som den negative spejling eller det "naturlige" modstykke til det danske. Og netop opfattelsen af en vis antagonisme og en stadig markering af grænsedragningen mellem den folkelige opfattelse af de to identiteter er det, der er grundlæggende i splittelsens diskurs. Som en kendt debattor og interviewperson udtrykker det: "Man er enten gronlænder eller dansker" (min kursivering). Dette suppleres af en yngre interviewperson: "Vi er ikke en og samme befolkning. Men det er to kulturer ...". Splittelsen eller narmest skizofrenien er dermed helt fundamental for selvforståelsen, for relationerne mellem de to samfundsgrupper og for den politik, som fores i Grønland. Den gennemsyrer alt samfundsliv i Gronland, idet kulturen etnificeres og gores til en kampplads.

I den oplevede kamp mellem henholdsvis "gronlandskheden" og "danskheden" er det naturligt, at hver af de to grupper forsøger at definere sig selv positivt - men som en negativ spejling - $i$ forhold til den kulturelle Anden. Inden for splittelsens diskurs kan man derfor hos gronlændere iagttage en tendens til pá den ene side at fole et kollektivt mindrevard og pa den anden side at forsoge aktivt at understrege en betydelig stolthed over deres identitet.

Splittelsens diskurs dækker sâledes over en tænkning og ordning i "rene" 
kategorier af enten dansk eller grønlandsk. Individer kan godt krydse grænser, men disse kategorier holdes rene, som en interviewperson, der er forsker, indprentede mig. Dette giver også anledning til en særlig "splittelsens metaforik" - for at benytte endnu et sørensensk udtryk. Splittelse og blanding bliver anset som noget mindre heldigt netop fordi de to etniske og kulturelle identiteter opfattes som grundlaggende antitetiske.

Denne tankegang har voldsomme sociale konsekvenser, for i praksis blander folk kategorierne i ét væk, jf. nedenfor. Så ikke alene skaber splittelsens diskurs en splittelse langs de opfattede etniske grænser mellem "dansk" og "gronlandsk", tilmed skaber denne diskurs en intern splittelse på tvars af den etniske gronlandske gruppe. På den måde fører splittelsens diskurs altså også til en udbredt opfattelse af, at grønlandskheden kan gradbøjes.

\section{Kulturpolitiseringens betydning i debatten om gronlandsk selvstændighed}

For at forstå forholdet mellem splittelsens diskurs og debatten om gronlandsk selvstændighed er det nødvendigt at beskrive, hvorledes kulturel identitet politiseres $\mathrm{i}$ Grønland omkring århundredeskiftet.

\section{Den gronlandske nationalisme}

I konsolideringen af den nuværende nationsdannelsesproces forekommer en tydelig politisering af kulturelle argumenter både til fordel for en etnisk, gronlandsk nationalisme og for en pangrønlandsk nationalisme. Min vurdering er, at tendensen i øjeblikket er, at den etnisk, grønlandske nationalisme er stærkest. Den pan-gronlandske nationa- litetsfølelse findes naturligvis også, og man kan ogsả finde eksempler pả den $\mathrm{i}$ den offentlige debat. Men den er (endnu?) ikke så markant som den anden strømning.

Den etnisk, grønlandske nationalisme er en direkte udløber af splittelsens diskurs, og den resulterer ofte i en slags hypernationalisme, hvor kulturen făr et overvældende instrumentelt præg med henblik på at skabe en grænsedragning $\mathrm{i}$ forhold til den kulturelle Anden. Desuden ser man tydeligt en tingsliggørelse af den såkaldte grønlandskhed. Bygderne, fangerlivet, kajakken og hundeslæden fremhæves gang på gang som symboler på grønlandskhed, jf. valgkampen frem mod Landstingsvalget $\mathrm{i}$ februar 1999.

Under alle omstændigheder har grænsedragningen mellem henholdsvis den grønlandske og den danske del af befolkningen stor betydning for det krav om grønlandsk selvstændighed, som igen er blomstret op i de sene 1990'ere. I starten af artiklen blev en strofe fra den grønlandske nationalsang derfor også citeret. Jeg tolker citatet som et opråb til det gronlandske folk om at ryste underkastelsens åg af sig, tro på sig selv og sine evner og begynde at kæmpe for frihed i selvstændighedens klæder. Selv i nationalsangen fra 1912 ser man således den fortsat relevante grønlandske følelse af subordination samt det gryende håb om frihed.

\section{Selvstandighedsonsket}

Spørgsmålet er dog, hvilken selvstændighed der ønskes, af hvem og hvorfor. Disse spørgsmål er ikke lette at besvare, idet debatten om grønlandsk selvstændighed i 1998-99 i stor udstrækning har været præget af det, som en af interviewpersonerne kalder "semantisk rod". Det er søgt illustreret i figur 1 . 
Figur I. Illustration af opfattelsen af den onskede selvstendigheds karakter

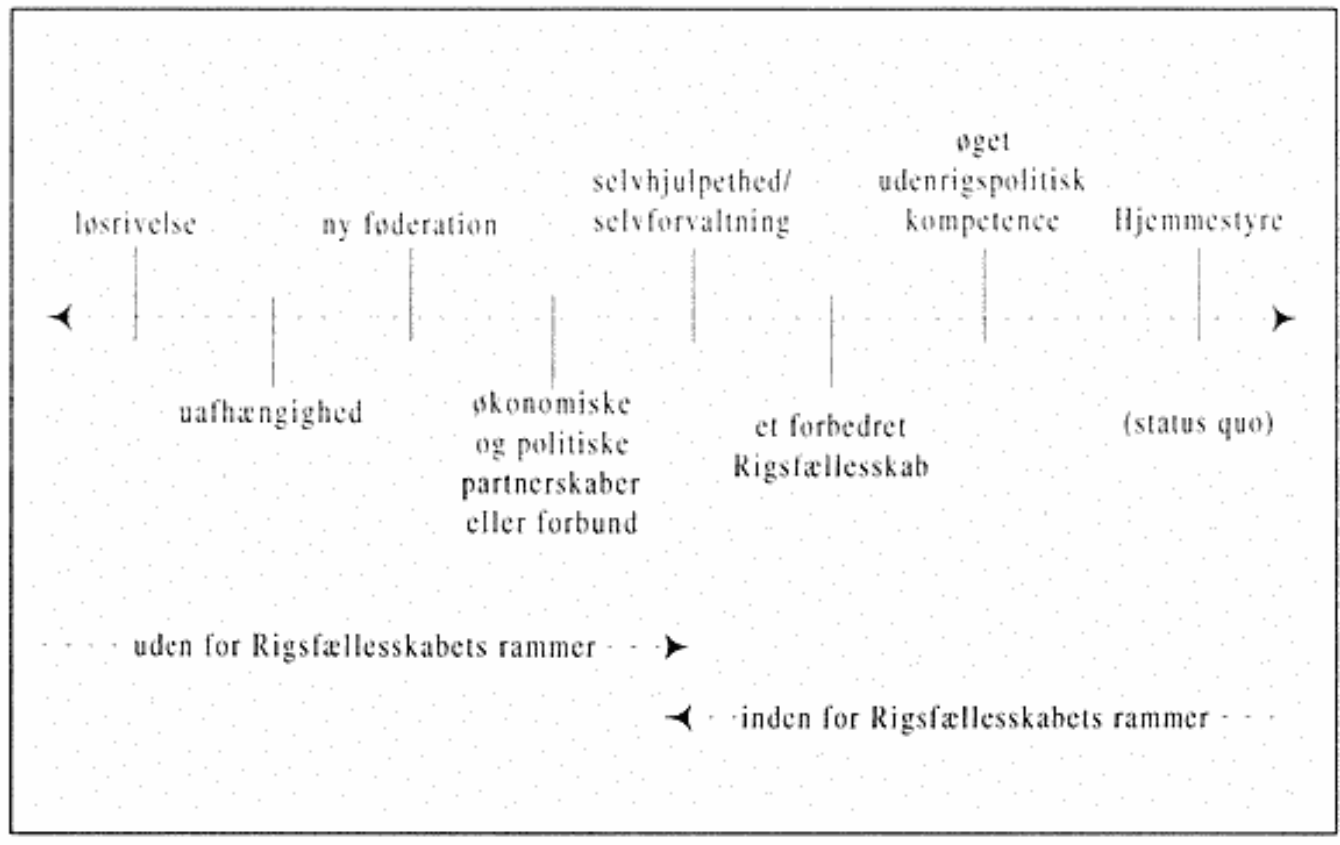

I den ene ende af kontinuet finder man en opfattelse af selvstændighed som regulær løsrivelse fra rigsfællesskabet, mens selvstandighed i den anden ekstrem tolkes nærmest som status quo eller som en vis udvidelse af hjemmestyret. Man kan ikke plotte de forskellige tolkninger ind på en politisk højre/venstre skala endsige konkludere, at de samme personer altid har den samme vurdering af begrebet. Jeg vil derfor give en af interviewpersonerne ret $\mathrm{i}$, at selvstændighedsbegrebet kan "gradbojes" alt efter behov. Der findes altså ikke en entydig forståelse af selvstændighedsønsket, som fremsættes i den offentlige debat $\mathrm{i}$ både aviser, $\mathrm{t}$, radio og pă internettet i perioden 1998-99. Da debatten er karakteriseret ved en manglende falles forstấelse af selvstændighedsonsket, skabes der betydeligt rum for politisering af de argumenter, som inddrages i diskussionen, herunder de kulturelle argumenter.
I selvstændighedsdebatten må man sondre mellem argumenter for selvstandighed som 1) et mål i sig selv qua identiteten som et sarligt folk med en sarlig kulturel identitet $o g$ argumenter for selvstandighed som 2) et middel til at nå andre măl såsom frihed fra underkastelse og dominans. Falles for de to opfattelser er, at de begge udspringer af det koloniale syndrom, og at de accentueres inden for splittelsens diskurs, hvorved det særligt bliver den etnisk, gronlandske argumentation om et Gronland for etniske gronlandere, som făr den største klangbund. Denne argumentation synes stærk, om end den ikke dakker over hverken et entydigt selvstændighedsbegreb eller en fælles forståelse for, hvad man onsker at opnå med selvstandigheden.

Kvantitative data illustrerer, at man generelt må konkludere, at der i Gronland findes et stærkt onske om selvstændighed. Dette kan blandt andet læses ud af avisen Sermitsiaq, som fik foretaget 
en meningsmåling i sommeren 1998 . der viste, at 78 pct. af befolkningen $i$ Gronland onsker selvstændighed nu eller på et senere tidspunkt." Derudover fik selvstændighedsbevægelsen Namineq en hel del mediedækning i perioden 1998/99 (ikke mindst i Danmark). Desuden indeholdt valgkampen op til Landstingsvalget i februar 1999 et betydeligt fokus på selvstændighedsønsket uanset partifarve. Valget resulterede i en situation, hvor partierne med den kraftigste profil for selvstændighed (primært IA og det såkaldte Kandidatforbund ") gik frem. IA's efterfølgende rolle som koalitionspartner i Landsstyret har desuden bevirket, at selvstændighedsønsket faktisk er blevet til en del af regeringsgrundlaget.

\section{Ideologi versus praksis}

Det er dog nødvendigt at forholde sig kritisk til splittelsens diskurs og til det udtalte onske om selvstændighed, som fremstilles på baggrund af denne. For når man ser nærmere på det grønlandske samfund på kanten til det næste årtusinde, fắr man øje på et samfund, som i høj grad ikke kan beskrives med ord som fundamental splittelse, stigmatisering og undertrykkelse.

Jeg mener således at kunne vurdere, at der er tre afgørende aspekter ved det grønlandske samfund, som ikke stemmer overens med splittelsens diskurs, nemlig: 1) opfattelsen af den kulturelle identitet som enten/eller, 2) billedet af en kultur præget af adskillelse og grundlæggende væsensforskellighed samt 3 ) en samfundsstruktur karakteriseret ved dybe skillelinier, der alle følger den etniske linie mellem dansk og grønlandsk.

Det identitetsmassige kontinuum

For det første fremhæver en række in- terviewpersoner, at det er misvisende alene at tale om gronlandskhed versus danskhed. Virkeligheden er langt mere broget og kompleks. I tråd med den socialkonstruktivistiske diskurs understreger disse interviewpersoner, at man i stedet bør opfatte kulturel identitet som noget dynamisk og foranderligt. Kulturel identitet er for dem ikke et spørgsmål om enten/eller. I deres øjne udelukker én identitet ikke nødvendigvis en anden. Man kan derfor godt jonglere rundt med flere identiteter på én gang, jf. den socialkonstruktivistiske forestilling om identitetscirkler. En af interviewpersonerne pointerer, at det etniske billede $\mathrm{i}$ Grønland er et kontimutu - en slags skala, snarere end et spørgsmăl om enten/eller. Og hun understreger, at "... dem, der bor i Grønland, befinder sig på hele skalaen".

Denne opfattelses af et identitetsmæssigt kontinuum bekræftes også af andre interviewpersoner. Det understreges gang på gang, at man sagtens kan glide frem og tilbage ad skalaen, uden at dette nødvendigvis skaber identitetskonflikter. Om man kalder sig grønlandsk, inuk," eskimo eller beboer i Nuuk er altså noget, som kan variere alt efter sammenhængen. På baggrund af interviewpersonernes udsagn mener jeg (i hvert fald i Nuuk) at kunne konstatere et faktisk etnisk kontinuum - versus den forestillede identitetsmæssige splittelse (se figur 2).

\section{Blandingskulturen}

Hybrididentiteten dækker over forestillingen om, at identiteter til stadighed konstrueres socialt ved, at de interagerer med og stykkes sammen af andre, allerede eksisterende identiteter. Derved kan en helt ny identitet konstrueres - en såkaldt hybrid. Hybrididentiteter kan 
Figur 2. Det etniske kontinuum i Gronland"

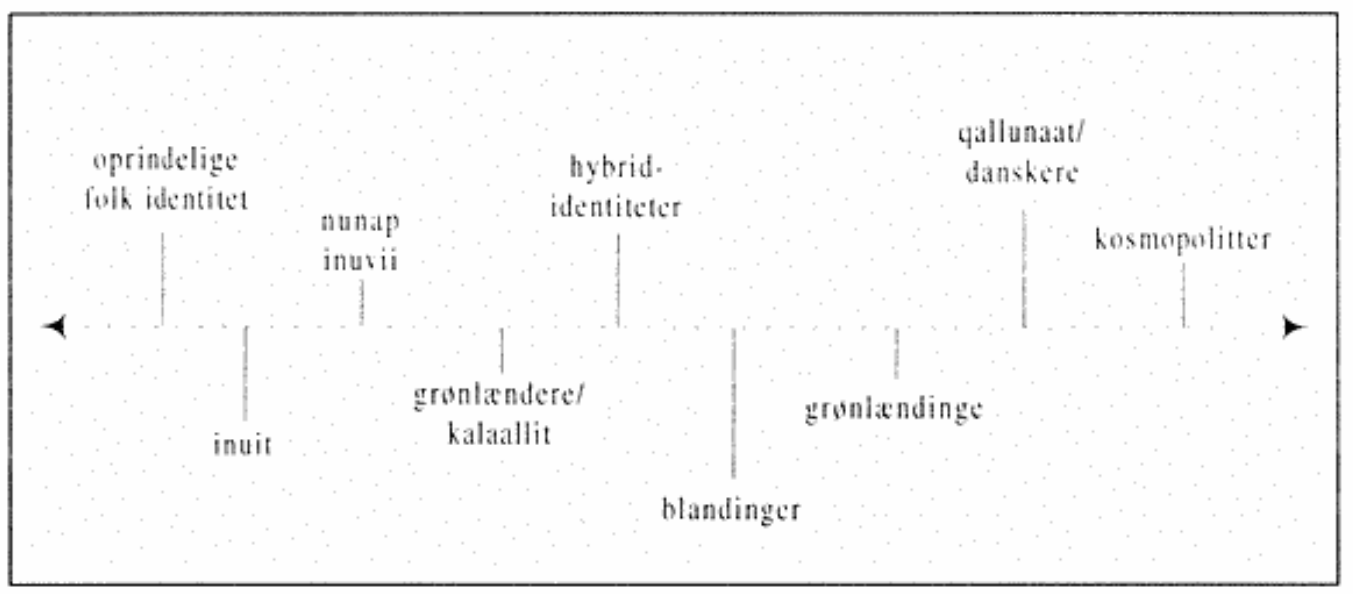

ofte iagttages i blandingskulturer, hvor mennesker med forskellige kulturelle identiteter mødes og interagerer. Grønland er efter min mening netop udtryk for en sâdan blandingskultur.

Snarere end at være et balkaniseret samfund, hvor de to dominerende etniske grupper - den gronlandske og den danske - lever segregerede fra hinanden, er det grønlandske samfund (og især det nuukske samfund ${ }^{17}$ ) $\mathrm{i}$ høj grad præget af sameksistens grupperne imellem. Man mødes i skolen, på hospitalet, på job osv. En af interviewpersonerne bruger da også netop begrebet "blandingskultur" om livet i Nuuk.

\section{Skillelinier på kryds og tvers}

Endelig mener jeg, at det er yderst problematisk at fastholde et billede af splittelse også på det socioøkonomiske plan. Hvis man ser på den sociookonomiske udvikling $\mathrm{i}$ Gronland $\mathrm{i}$ de seneste 20 år, vil man nemlig kunne konstatere, at det ikke langere giver mening at tale om et samfund karakteriseret ved gensidigt forstærkende skillelinier. Skillelinierne i samfundet $i$ dag følger og forstærker ikke længere hinanden ud fra et monster, som er centreret omkring den etniske grænsemarkor. Tværtimod tegner der sig i dag et billede af et grønlandsk samfund, hvor økonomiske og sociale skillelinier snarere går på kryds og tværs af de etniske grupperinger.

Der er altså ikke i dag tale om to tydeligt adskilte etniske grupper - hverken på det kulturelle eller på det socioøkonomiske felt. Men selvom der ikke længere er tale om den splittelse, som tidligere var til stede, så må man ikke desto mindre konkludere, at splittelsens diskurs lever videre $\mathrm{i}$ bedste velgående. Men det er kun på det normative plan.

\section{Den mudrede virkelighed}

Konklusionen bliver derfor uvagerligt, at der i Gronland i dag eksisterer et voldsomt skisma mellem henholdsvis ideologi og praksis. Mens splittelsens diskurs $\mathrm{i}$ høj grad stadig opretholdes som ideologi, som normativ model og som udgangspunkt blandt andet for selvstændighedsønsket, sẫ viser det sig samtidig, at praksis - det levede liv i Gronland - præges af interaktion, blandinger og hybriditet.

Ârsagen til dette skisma må søges i det koloniale syndrom, som stadig reproduceres både af gronlændere og dan- 
skere. Selvom der i dag hverken findes egentlig magt bag - eller objektiv definerbar begrundelse for - stigmatiseringen af den grønlandske identitet, så er splittelsens diskurs en slags selvopfyldende spådom, hvis onde cirkel ikke kan brydes fra det ene øjeblik til det andet. Det tager lang tid at ændre de grundlæggende normer og værdier i et samfund - billeder af os og dem. Derfor har splittelsens diskurs stadig så stor udbredelse og indflydelse som ideologi - på trods af, at den identitetsmæssige praksis og den socioøkonomiske udvikling har skabt et samfund præget af mobilitet, forandring og blanding.

\section{Noter}

1. Kalaallit er det grønlandske ord for gronlændere.

2. På dansk ved W. Thalbitzer og senere Mads Lidegaard i Mikkelsen (1998).

3. Artiklen er skrevet på baggrund af forfatterens speciale afleveret ved Kobenhavns Universitet, Institut for Statskundskab, i sommeren 1999. Den empiriske del af specialet bygger på henholdsvis kvantitative og kvalitative data. De kvantitative data stammer fra en meningsmåling vedrørende onsket om gronlandsk selvstæendighed foretaget for avisen Sermitsiaq i sommeren 1998 samt resultaterne fra landstingsvalget i februar 1999. De kvalitative data er skabt gennem interviews med 20 personer foretaget i København og Nuuk i perioden december 1998 til februar 1999. Interviewpersonerne er både danskere og gronlændere, og de reprasenterer henholdsvis gronlandseksperter (eksperter med særlig viden om grønlandske forhold og oprindelige folk) og/eller dagsordensættende personer (mennesker, som direkte lader deres holdning om onsket om grønlandsk selvstændighed komme til udtryk i den offentlige debat i Gronland og/eller Danmark).

4. I diskussionen om kultur og identitet resulterer stabilitetsprincippet $i$ et psykisk betinget forsøg på at ordne sociale og kulturelle fæn- omener i săkaldte "rene" eller enkle kategorier af for eksempel gronlandere eller danskere. Accept og forstăelse for muligheden af identitetsmæssig hybriditet kan således være svaert opnåelig (Hansen, 1997).

5. Sartre opererer med distinktionen "vi-folelse" over for "os-følelse". Sartre i Eriksen (1993a: 67).

6. Jf. Lijpharts cleavageteori (1984).

7. Mine interviewpersoner har dog kunnet navne en rakke karakteristika ved den săkaldte grønlandskhed så som: at leve i pagt med naturen, tolerance, konfliktskyhed, folelsesfuldhed, gronlandsksproget kompetence, hægen om fællesskabet, fokus på den historiske kontinuitet, solidaritetsfolelse, medlemskab af gruppen nunap inuvii (landets forste mennesker eller oprindelige folk) samt stolthed over gronlandskheden. Listen skal ikke forstås bogstaveligt som særlige gronlandske dyder eller lyder. Den skal blot forstås som interviewpersonernes forsøg pâ indkredsning af det diffuse begreb "grønlandskhed".

8. Denne figur viser spredningen $\mathbf{i}$ opfattelsen af, hvad ønsket om selvstæendighed måtte betyde. De forskellige karakteristikker af selvstændighed skal ikke forstås som relaterede til hinanden på en logisk stringent facon. Snarere skal figuren illustrere den inkonsekvens og brede fortolkningsmargin, som findes $\mathrm{i}$ den måde, hvorpå selvstændighed beskrives og karakteriseres $\mathrm{i}$ den grønlandske debat.

9. Meningsmålingen kan udsættes for en del metodisk kritik. Derudover skal det nævnes, at der i målingen blev foretaget en sammenkædning mellem politisk selvstændighed $\mathrm{og}$ grønlandsk økonomi.

10. Kandidatforbundet er en liste af uafhængige enkeltpersoner. Partiet Inuit Ataqatigiit (IA) er et venstrefløjsparti.

11. Inuk er entalsformen af inuit og betyder menneske.

12. Det etniske kontinuum har naturligvis ikke nogen faste yderpunkter, idet man med kontinuumtanken bevager sig inden for den postmoderne diskurs, inden for hvilken tankegang nye identiteter til stadighed konstrueres, og gamle forgår. Figuren er blot et forsøg på at "tage temperaturen" på mine interviewpersoners opfattelse af deres egen etniske identitet. 
13. Der kan vare en betydelig forskel pá den kulturelle udvikling i Nuuk og i resten af Gronland. Mit kvalitative researchyrundlag begranser sig desvarre til Nuuk.

\section{Litteratur}

Eriksen. Thomas Hylland (1993a). Ethmicity and Nationalism, London: Pluto Press.

Eriksen. Thomas Hylland (1993b). "Fleretniske Paradokser - En Kritisk Analyse av Multikulturalismen", i Grus ur. 41, pp, 66-82. Hansen, Finn Thorbjorn (1997). Kunsten at Navigere $i$ Kaos - om Dannelse af Identitet $i$ en Multikulturel Verden. Vejle: Kroghs Forlag A/S.
Lijphart. Arendt (1984). Democracies, New Haven: Yale University Press.

Malkki. Liisa (1992), "National Geographic: The Rooting of Peoples and the Territorialization of National Identity Among Scholars and Refugees". i Cultural Anthropologr nr. 7. pp. $24-38$.

Mikkelsen, Hanne Guldberg (1998). Inuit og den Lange faj. Gronlands historte. Kobenhavn: Gyldendal Undervisning.

Sormitsiay (1998), nr, 25.

Sorensen. Bo Wagner (1994). Magf aller dfmagt? Kon. Folelser og lold $i$ Gronland. Arhus: Akademisk Forlag $\mathrm{A} / \mathrm{S}$. 
13. Der kan vare en betydelig forskel pá den kulturelle udvikling i Nuuk og i resten af Gronland. Mit kvalitative researchyrundlag begranser sig desvarre til Nuuk.

\section{Litteratur}

Eriksen. Thomas Hylland (1993a). Ethmicity and Nationalism, London: Pluto Press.

Eriksen. Thomas Hylland (1993b). "Fleretniske Paradokser - En Kritisk Analyse av Multikulturalismen", i Grus ur. 41, pp, 66-82. Hansen, Finn Thorbjorn (1997). Kunsten at Navigere $i$ Kaos - om Dannelse af Identitet $i$ en Multikulturel Verden. Vejle: Kroghs Forlag A/S.
Lijphart. Arendt (1984). Democracies, New Haven: Yale University Press.

Malkki. Liisa (1992), "National Geographic: The Rooting of Peoples and the Territorialization of National Identity Among Scholars and Refugees". i Cultural Anthropologr nr. 7. pp. $24-38$.

Mikkelsen, Hanne Guldberg (1998). Inuit og den Lange faj. Gronlands historte. Kobenhavn: Gyldendal Undervisning.

Sormitsiay (1998), nr, 25.

Sorensen. Bo Wagner (1994). Magf aller dfmagt? Kon. Folelser og lold $i$ Gronland. Arhus: Akademisk Forlag $\mathrm{A} / \mathrm{S}$. 